Dept. of Food Control,

Faculty of Veterinary Medicine, Zagazig University

\title{
MICROBIOLOGICAL RESEARCH ON SOME DAIRY PRODUCTS
}

(With 6 Tables)

\author{
S.F. AHMED ABD ELAAL
}

(Received at 28/8/2008)

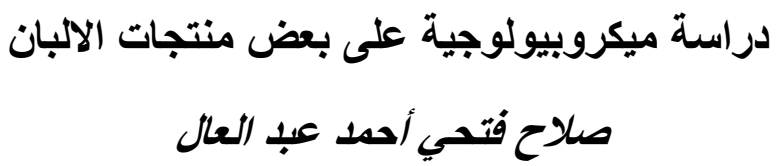

أجريت هذه الدر اسة علي مائة عينة من منتجات الألبان (25 من كل من اللبن المعامل حر ارياً

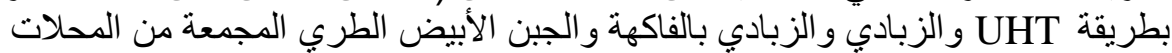

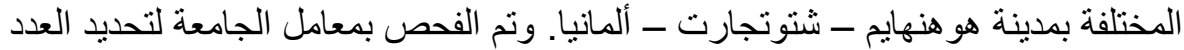

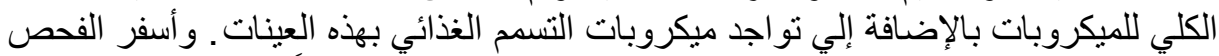

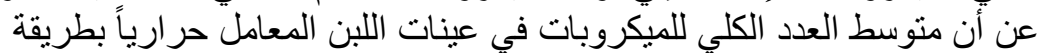

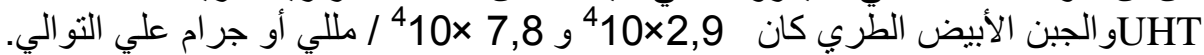

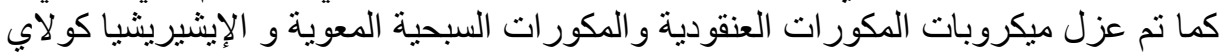

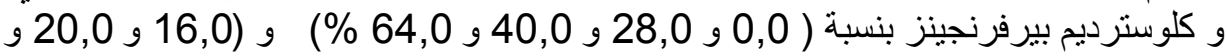

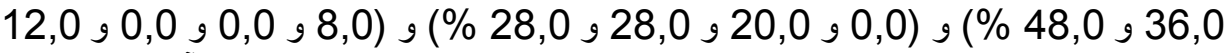

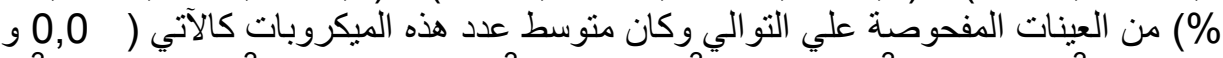

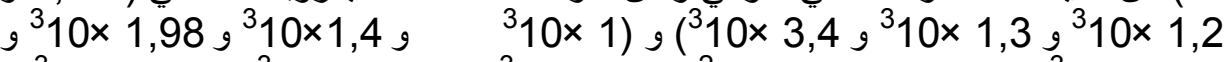

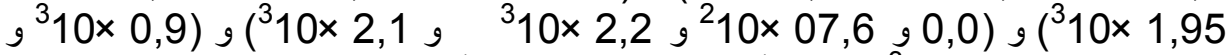

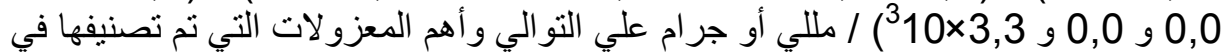

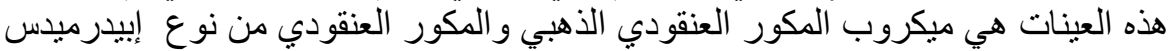

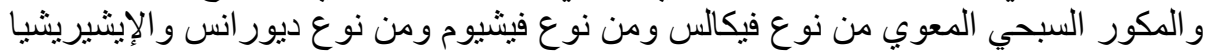

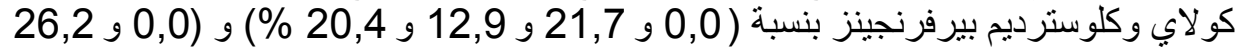

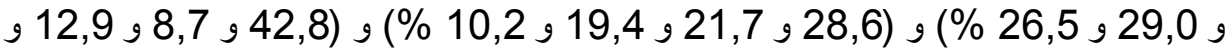
14,3 \% و (0,0) و 0,0 و 0,0,0,

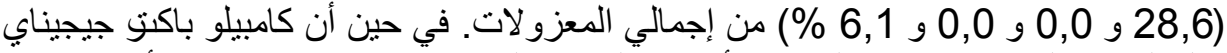

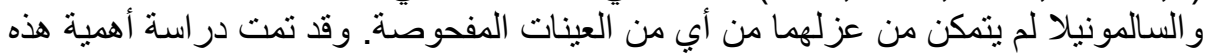

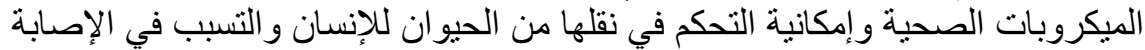

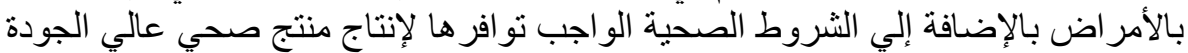

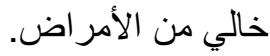


One hundred samples of dairy products (25 each) of UHT milk, plain yoghurt, fruit yoghurt and white soft cheese samples were examined for total viable count, and the presence of foodborne pathogenic microorganisms. The results declared that the mean total bacterial counts $/ \mathrm{ml}$ or gm were $2.9 \times 10^{4}$ and $7.8 \times 10^{4}$ in examined UHT milk and white soft cheese samples, respectively. Staphylococci, Enterococci, E. coli, and Clostridium perfringens were detected in (0.0, 28.0, 40.0 and $64.0 \%) \&(16.0,20.0,36.0$ and $48.0 \%) \&(0.0,20.0,28.0$ and $28.0 \%)$ and $(8.0,0.0,0.0$ and $12.0 \%)$ of examined samples, respectively. The mean values of isolated organisms $/ \mathrm{mL}$ or gm were $\left(0,1.2 \times 10^{3}, 1.3 \times 10^{3}\right.$ and $\left.3.4 \times 10^{3}\right) \&\left(1 \times 10^{3}, 1.4 \times 10^{3}, 1.98 \times 10^{3}\right.$ and $\left.1.95 \times 10^{3}\right) \&(0,7.6$ $\times 10^{2}, 2.2 \times 10^{3}$ and $\left.2.1 \times 10^{3}\right)$ and $\left(0.9 \times 10^{3}, 0,0\right.$ and $\left.3.3 \times 10^{3}\right)$, respectively. The predominant isolated bacterial stains were Staphylococcus aureus, Staphylococcus epidermidis, Enterococcus faecalis, Enterococcus faecium, Enterococcus durans, E. coli, and Clostridium perfringens by frequency distribution of $(0.0,21.7,12.9$ and $20.4 \%) \&(0.0,26.2,29.0$ and $26.5 \%) \&(28.6,21.7,19.4$ and $10.2 \%)$ $\&(42.8,8.7,12.9$ and $14.3 \%) \&(0.0,0.0,3.2$ and $8.2 \%) \&(0.0,21.7$, 22.6 and $14.3 \%)$ and $(28.6,0.0,0.0$ and $6.1 \%)$ of total isolates, respectively. Meanwhile, Campylobacter jejuni and Salmonellae failed to be detected in all examined samples. The sanitary and public health importance of these organisms as well as control measures to improve the quality of dairy products and to safeguard the consumers from infection were discussed.

Key words: Microbiological, quality dairy products

\section{INTRODUCTION}

Dairy products have generally been considered an excellent source of high-quality protein, calcium, potassium, phosphorus, magnesium, zinc, and the B vitamins riboflavin, niacin, vitamin B-6, and vitamin B-12 (Buttriss, 1997).

Many methods of food preservation are used for ensuring microbiological safety, among which UHT. In UHT processing, the milk is heated before its packaging and then sealed into sterilized containers in a sterile environment. The use of higher temperature $135-142^{\circ} \mathrm{C}$ for few seconds will increase the microbial death rate more than the loss of milk quality associated with thermal reactions (Adams and Moss, 1995). UHT seems a very promising technique as it offers numerous 
opportunities for developing new stable milk with extended shelf life, high nutritional value and excellent organoleptic characteristics. UHT milk minimally processed but safe for consumers and the product requires no refrigeration (Fonberg-Broczek et al., 1999).

Yoghurt is defined by the coagulated milk product that results from the fermentation of lactic acid in milk by Lactobacillus bulgaricus and Streptococcus thermophilus (Bourlioux and Pochart, 1988). Components of the human intestinal microflora and of the food entering the intestine may have harmful or beneficial effects on human health. Abundant evidence implies that specific bacterial species used for the fermentation of dairy products such as yoghurt and selected from the healthy gut microflora have powerful antipathogenic and antiinflammatory properties. These microorganisms are therefore involved with enhanced resistance to colonization of pathogenic bacteria in the intestine, which has led to the introduction of novel modes of therapeutic and prophylactic interventions based on the consumption of monocultures and mixed cultures of beneficial live microorganisms as "probiotics" (Guarner and Schaafsma, 1998).

Cheese is an excellent food containing a wide variety of easily digested nutrients; its importance in human nutrition lies not only in supplying the consumer with a high quality protein, but also, it is rich in the essential amino acids. It contains high fat percentage, which supplies the consumer with the essential fatty acids, phospholipids and energy. Cheese is extremely an economical food, more than $90 \%$ of the assimilated material being changed into body tissues or energy and because cheese contains all essential amino acids, it is considered the main protein supplement to farmers and most people. A great variety of cheeses are produced through traditional dairy technologies and widespread all over the world. Cheese quality is greatly influenced by the complex microbial flora from the raw milk which together with that arising from the processing environment, contributes to milk acidification, curd production and ripening often leading to final products with distinctive flavours and taste (Mauriello et al., 2003). However, it can be contaminated by pathogenic m.os., thus compromising the safety of cheese and representing a hazard for consumers (Maguire et al., 1991).

Milk and products derived from milk of dairy cows can harbor a variety of microorganisms and can be important sources of foodborne pathogens (Oliver et al., 2005). Milk products are an excellent environment for growth of pathogenic microorganisms, which may 
cause foodborne diseases. Quality and shelf life of these products depends greatly on the properties of the m.os. contaminating the product. Despite the introduction of food standards obligatory in EU countries, epidemiologists believe that $75 \%$ of foodborne diseases are caused by bacteria (CAC, 2003). For this reason, the control of microorganisms is an important aspect of the food quality and safety.

Staphylococci, Enterococci, Escherichia coli, Salmonellae, Clostridium perfringens, and Campylobacter jejuni are the most important foodborne pathogens that are widely distributed throughout the environment. They have been associated with sever food poisoning outbreaks and often found in milk and dairy products (Condera et al., 2004). The aim of this study was to estimate the pathogenic bacteria that contribute a major threat to the safety of dairy products and the involvement of these dairy products in foodborne diseases.

\section{MATERIALS and METHODS}

\section{Collection of samples:}

One hundred samples of dairy products (25 each) of UHT milk, plain yoghurt, fruit yoghurt and white soft cheese samples were collected in their retail packs from different localities, markets and shops in Stuttgart, Germany. The collected samples were transferred in an insulated ice-box to the laboratory with a minimum of delay for examination.

\section{Preparation of samples:}

A- UHT milks (Longeveld, et al., 1976): Each sample of UHT milk was thoroughly mixed before being subjected to bacteriological examination. The surface of the retail packs was thoroughly swabbed with $70 \%$ alcohol. A sterile, single-service hypodermic needle of syringe inserted through the package wall for bacteriological examination.

B- Yoghurt samples (A.P.H.A., 1992): Eleven (11) grams of the prepared sample were added to $99 \mathrm{ml}$ of sterile distilled water $\left(40-45^{\circ} \mathrm{C}\right)$, shaken until a homogenous dispersion is obtained to obtain dilution 1/10 from which decimal dilutions were prepared using a sterile peptone water solution $0.1 \%$.

C- Cheese samples: (A.P.H.A., 1992): Eleven (11) grams of cheese sample was transferred aseptically to a sterile blender then add $99 \mathrm{ml}$ sterile, freshly prepared aqueous solution of $2 \% \mathrm{Na}$ citrate (sodium citrate) at $40-45^{\circ} \mathrm{C}$. Mix for $2 \mathrm{~min}$ and invert the blender container to rinse particles from the interior wall then remix for approximately 10 
sec. Mix thoroughly till complete emulsification to make dilution 1:10, from which decimal dilutions were prepared using a sterile peptone water solution $0.1 \%$.

Microbiological examination: The prepared samples were subjected to the following examination:

1- Preparation of serial dilution (A.P.H.A., 1992): One $\mathrm{ml}$ of each prepared sample was added to $9 \mathrm{ml}$ of sterile peptone water solution $0.1 \%$ to make serial decimal dilutions.

2- Total colony count (A.P.H.A., 1992): One $\mathrm{ml}$ from the previously prepared dilution was inoculated onto duplicates of standard plate count (SPC) agar and incubation at $37^{\circ} \mathrm{C}$ for $24 \mathrm{~h}$.

3- Staphylococci count (Chapman, 1945): $0.1 \mathrm{ml}$ from the previously prepared dilutions of the examined samples was transferred and evenly spread on the surface of Mannitol salt agar medium (Oxoid, 1990) plates. Inoculated plates were incubated at $37^{\circ} \mathrm{C}$ for $48 \mathrm{~h}$. and Staphylococci count $/ \mathrm{mL}$ was calculated and recorded.

4- Enterococci count (Gelsomino et al., 2003): $0.1 \mathrm{ml}$ from the previously prepared dilutions of the examined samples was inoculated on the surface of kanamycin esculin azide agar (kAA; Merck, Darmstadt, Germany) at $37^{\circ} \mathrm{C}$ for $24 \mathrm{~h}$.

5- E. coli count (Bacteriological Laboratory of Hygiene and Environment Institute): $0.1 \mathrm{ml}$ from the previously prepared dilutions of the examined samples was spread onto Targitol medium and Endo medium (Oxoid, 1990) then incubation at $37^{\circ} \mathrm{C}$ for $24 \mathrm{~h}$.

6- Isolation of Salmonella spp. (Jayarao and Henning, 2001):

*Pre-enrichment: $25 \mathrm{ml}$ from the previously prepared sample added to $225 \mathrm{ml}$ peptone water with Novobiocin (Standard: $100 \mathrm{mg} / 1 \mathrm{ml}$ sterile D.W. \& Test: $0.9 \mathrm{ml}$ prepared solution/225) then incubated at $37^{\circ} \mathrm{C}$ for $24 \mathrm{~h}$.

*Selective enrichment: One ml peptone water from previously prepared pre-enrichment added to $10 \mathrm{ml}$ Rappaport Vassiliadis broth, Difco Laboratories (Two tubes) after that one tube incubated at $37^{\circ} \mathrm{C}$ for $24 \mathrm{~h}$. and the second at $43^{\circ} \mathrm{C}$ for $24 \mathrm{~h}$.

*Plating on selective medium: $0.1 \mathrm{ml}$ of incubated Rappaport evenly spread on the surface of Xylose Lysine Desoxycholate (XLD) and Brillient Green Phenol Red Lactose Sucrose (BPLS) plates, Unipath Co. Inoculated plates were incubated at $37^{\circ} \mathrm{C}$ for $24 \mathrm{~h}$. and $43^{\circ} \mathrm{C}$ for $24 \mathrm{~h}$.

7- Anaerobic spore formers count (Bacteriological Laboratory of Hygiene and Environment Institute): Using Thioglucolate medium (Oxoid, 1990). 
$* 1 \mathrm{ml}$ of prepared sample in 3 tubes of Thioglucolate, heating at $70^{\circ} \mathrm{C}$ for $20 \mathrm{~min}$ and incubated at $37^{\circ} \mathrm{C}$ for $24 \mathrm{~h}$. anaerobically (anaerobic jar with anaerobic anaerocult A sachet moisted with $17 \mathrm{ml} \mathrm{D.W.).}$

$* 1 \mathrm{ml}$ from the previously prepared serial dilution in 3 tubes of Thioglucolate, heating at $70^{\circ} \mathrm{C}$ for $20 \mathrm{~min}$ and incubated at $37^{\circ} \mathrm{C}$ for 24 h. anaerobically.

*Loopfuls from previously incubated tubes were streaked on blood glucose agar plate. The inoculated plates were incubated at $37^{\circ} \mathrm{C}$ for $48 \mathrm{~h}$. anaerobically. Specific colonies grew surrounded by large zone of haemolysis.

8- Isolation and Identification of Campylobacter (Hunt et al., 2001): *Selective enrichment: $1 \mathrm{ml}$ from prepared sample and $9 \mathrm{ml}$ Preston selective enrichment broth. Then incubated at $43^{\circ} \mathrm{C}$ for $48 \mathrm{~h}$. in microaerophilic atmosphere (anaerobic jar with anaerocult $\mathrm{C}$ sachet of micoaerophilic organism moisted with 6 mL D.W.), Oxoid Ltd., Basing Stoke, UK.

*Plating on selective medium: $0.1 \mathrm{ml}$ of Preston broth enrichment put on filter type AC(pore size, $0.45 \mu \mathrm{m}$ ) on the surface of Campylobacter agar medium (Columbia Agar Base + Horse Blood + Campylobacter Selective Supplement Cod SR 204 E + Campylobacter Growth Supplement Code SR 084 E) incubation at $37^{\circ} \mathrm{C}$ for $2 \mathrm{~h}$. then remove the filter. Incubation of the media at $43^{\circ} \mathrm{C}$ for $48 \mathrm{~h}$. microaerophilic in anaerobic jar.

Identification of isolated organisms: Purified colonies were identified by using colony morphology, gram staining characteristics, oxidase, Catalase, coagulase production and biochemical reactions. Specific identifications were made using Commercial micro methods (API Staph for Staphylococci, API 20 Strept for Enterococci, API 20 E for E. coli, API 20 A for Clostridia and API Campy, Bio Merieux, France). Specific Serological tests were made for Salmonellae spp.: Polyvalent (I or II) and Monovalent.

\section{RESULTS}


Table 1: Statistical analytical results of total bacterial counts $/ \mathrm{ml}$ in examined UHT milk and White soft cheese samples.

\begin{tabular}{|c|c|c|c|c|c|c|c|}
\hline \multirow{2}{*}{$\begin{array}{c}\text { Examined } \\
\text { samples }\end{array}$} & \multirow{2}{*}{$\begin{array}{c}\text { Total No. } \\
\text { of } \\
\text { samples }\end{array}$} & \multicolumn{2}{|c|}{$\begin{array}{c}\text { Positive } \\
\text { samples }\end{array}$} & Min. & Max. & Mean & +S.E.M. \\
\cline { 3 - 4 } & 25 & 10 & 40.0 & $5 \times 10^{3}$ & $5 \times 10^{4}$ & $2.9 \times 10^{4}$ & $0.36 \times 10^{4}$ \\
\hline UHT milk & 25 & 18 & 72.0 & $2 \times 10^{4}$ & $23 \times 10^{4}$ & $7.8 \times 10^{4}$ & $1.1 \times 10^{4}$ \\
\hline $\begin{array}{c}\text { White soft } \\
\text { cheese }\end{array}$ & & &
\end{tabular}

*-ve samples $>100$

Table 2: Statistical analytical results of Staphylococci counts/ml in examined dairy product samples.

\begin{tabular}{|c|c|c|c|c|c|c|c|}
\hline \multirow{2}{*}{$\begin{array}{l}\text { Examined } \\
\text { samples }\end{array}$} & \multirow{2}{*}{$\begin{array}{c}\text { Total No. } \\
\text { of } \\
\text { samples }\end{array}$} & \multicolumn{2}{|c|}{$\begin{array}{l}\text { Positive } \\
\text { samples }\end{array}$} & \multirow[t]{2}{*}{ Min. } & \multirow[t]{2}{*}{ Max. } & \multirow[t]{2}{*}{ Mean } & \multirow[t]{2}{*}{ \pm S.E.M. } \\
\hline & & No. & $\%$ & & & & \\
\hline UHT milk & 25 & 0 & 0.0 & 0 & 0 & 0 & 0 \\
\hline Plain yoghurt & 25 & 7 & 28.0 & $4 \times 10^{2}$ & $2 \times 10^{3}$ & $1.2 \times 10^{3}$ & $0.11 \times 10^{3}$ \\
\hline Fruit yoghurt & 25 & 10 & 40.0 & $6 \times 10^{2}$ & $3.3 \times 10^{3}$ & $1.3 \times 10^{3}$ & $0.17 \times 10^{3}$ \\
\hline $\begin{array}{l}\text { White soft } \\
\text { cheese }\end{array}$ & 25 & 16 & 64.0 & $8 \times 10^{2}$ & $9 \times 10^{3}$ & $3.4 \times 10^{3}$ & $0.41 \times 10^{3}$ \\
\hline
\end{tabular}

* -ve samples > 100

Table 3: Statistical analytical results of Enterococci counts $/ \mathrm{ml}$ in examined dairy product samples.

\begin{tabular}{|c|c|c|c|c|c|c|c|}
\hline \multirow{2}{*}{$\begin{array}{l}\text { Examined } \\
\text { samples }\end{array}$} & \multirow{2}{*}{$\begin{array}{c}\text { Total } \\
\text { No. of } \\
\text { samples }\end{array}$} & \multicolumn{2}{|c|}{$\begin{array}{l}\text { Positive } \\
\text { samples }\end{array}$} & \multirow[t]{2}{*}{ Min. } & \multirow[t]{2}{*}{ Max. } & \multirow[t]{2}{*}{ Mean } & \multirow[t]{2}{*}{ \pm S.E.M. } \\
\hline & & No. & $\%$ & & & & \\
\hline UHT milk & 25 & 4 & 16.0 & $2 \times 10^{2}$ & $2.3 \times 10^{3}$ & $1 \times 10^{3}$ & $0.19 \times 10^{3}$ \\
\hline Plain yoghurt & 25 & 5 & 20.0 & $5 \times 10^{2}$ & $2.6 \times 10^{3}$ & $1.4 \times 10^{3}$ & $0.19 \times 10^{3}$ \\
\hline Fruit yoghurt & 25 & 9 & 36.0 & $8 \times 10^{2}$ & $3.5 \times 10^{3}$ & $1.98 \times 10^{3}$ & $0.15 \times 10^{3}$ \\
\hline $\begin{array}{c}\text { White soft } \\
\text { cheese }\end{array}$ & 25 & 12 & 48.0 & $1.2 \times 10^{3}$ & $4.9 \times 10^{3}$ & $1.95 \times 10^{3}$ & $0.20 \times 10^{3}$ \\
\hline
\end{tabular}

* -ve samples $>100$

Table 4: Statistical analytical results of E. coli counts $/ \mathrm{ml}$ in examined dairy product samples. 


\begin{tabular}{|c|c|c|c|c|c|c|c|}
\hline \multirow{2}{*}{$\begin{array}{l}\text { Examined } \\
\text { samples }\end{array}$} & \multirow{2}{*}{$\begin{array}{l}\text { Total No. } \\
\text { of samples }\end{array}$} & \multicolumn{2}{|c|}{$\begin{array}{l}\text { Positive } \\
\text { samples }\end{array}$} & \multirow[t]{2}{*}{ Min. } & \multirow[t]{2}{*}{ Max. } & \multirow[t]{2}{*}{ Mean } & \multirow[t]{2}{*}{ \pm S.E.M. } \\
\hline & & No. & $\%$ & & & & \\
\hline UHT milk & 25 & 0 & 0.0 & 0 & 0 & 0 & 0 \\
\hline Plain yoghurt & 25 & 5 & 20.0 & $3 \times 10^{2}$ & $13 \times 10^{2}$ & $7.6 \times 10^{2}$ & $0.74 \times 10^{2}$ \\
\hline Fruit yoghurt & 25 & 7 & 28.0 & $12 \times 10^{2}$ & $3.3 \times 10^{3}$ & $2.2 \times 10^{3}$ & $0.15 \times 10^{3}$ \\
\hline $\begin{array}{l}\text { White soft } \\
\text { cheese }\end{array}$ & 25 & 7 & 28.0 & $14 \times 10^{2}$ & $5.2 \times 10^{3}$ & $2.1 \times 10^{3}$ & $0.27 \times 10^{3}$ \\
\hline
\end{tabular}

*-ve samples $>100$

Table 5: Statistical analytical results Clostridium counts/ml in examined dairy product samples.

\begin{tabular}{|c|c|c|c|c|c|c|c|}
\hline \multirow{2}{*}{$\begin{array}{l}\text { Examined } \\
\text { samples }\end{array}$} & \multirow{2}{*}{$\begin{array}{c}\text { Total } \\
\text { No. of } \\
\text { samples }\end{array}$} & \multicolumn{2}{|c|}{$\begin{array}{l}\text { Positive } \\
\text { samples }\end{array}$} & \multirow[t]{2}{*}{ Min. } & \multirow[t]{2}{*}{ Max. } & \multirow[t]{2}{*}{ Mean } & \multirow[t]{2}{*}{ \pm S.E.M. } \\
\hline & & No. & $\%$ & & & & \\
\hline UHT milk & 25 & 2 & 8.0 & $1 \times 10^{2}$ & $1.7 \times 10^{3}$ & $0.9 \times 10^{3}$ & $0.22 \times 10^{3}$ \\
\hline Plain yoghurt & 25 & 0 & 0.0 & 0 & 0 & 0 & 0 \\
\hline Fruit yoghurt & 25 & 0 & 0.0 & 0 & 0 & 0 & 0 \\
\hline $\begin{array}{c}\text { White soft } \\
\text { cheese }\end{array}$ & 25 & 3 & 12.0 & $2.5 \times 10^{3}$ & $4 \times 10^{3}$ & $3.3 \times 10^{3}$ & $0.15 \times 10^{3}$ \\
\hline
\end{tabular}

* -ve samples > 10

Table 6: Frequency distribution of isolated bacterial stains in examined dairy product samples.

\begin{tabular}{|l|c|c|c|c|c|c|c|c|}
\hline \multirow{2}{*}{ Isolated bacterial stains } & \multicolumn{2}{|c|}{$\begin{array}{c}\text { UHT milk } \\
(\mathrm{n}=25)\end{array}$} & \multicolumn{2}{c|}{$\begin{array}{c}\text { Plain yoghurt } \\
(\mathrm{n}=25)\end{array}$} & \multicolumn{2}{c|}{$\begin{array}{c}\text { Fruit yoghurt } \\
(\mathrm{n}=25)\end{array}$} & \multicolumn{2}{c|}{$\begin{array}{c}\text { White soft } \\
\text { cheese } \\
(\mathrm{n}=25)\end{array}$} \\
\cline { 2 - 11 } & $\begin{array}{c}\text { No. of } \\
\text { isolates }\end{array}$ & F. & $\begin{array}{c}\text { No. of } \\
\text { isolates }\end{array}$ & F. & $\begin{array}{c}\text { No. of } \\
\text { isolates }\end{array}$ & F. & $\begin{array}{c}\text { No. of } \\
\text { isolates }\end{array}$ & F. \\
\hline Staph. Aureus & 0 & 0.0 & 5 & 21.7 & 4 & 12.9 & 10 & 20.4 \\
\hline Staph. Epidermidis & 0 & 0.0 & 6 & 26.2 & 9 & 29.0 & 13 & 26.5 \\
\hline Entrococcus faecalis & 2 & 28.6 & 5 & 21.7 & 6 & 19.4 & 5 & 10.2 \\
\hline Entrococcus faecium & 3 & 42.8 & 2 & 8.7 & 4 & 12.9 & 7 & 14.3 \\
\hline Entrococcus durans & 0 & 0.0 & 0 & 0.0 & 1 & 3.2 & 4 & 8.2 \\
\hline E. coli & 0 & 0.0 & 5 & 21.7 & 7 & 22.6 & 7 & 14.3 \\
\hline Clostridium perfringens & 2 & 28.6 & 0 & 0.0 & 0 & 0.0 & 3 & 6.1 \\
\hline Campylobacter jejuni & 0 & 0.0 & 0 & 0.0 & 0 & 0.0 & 0 & 0.0 \\
\hline Salmonellae & 0 & 0.0 & 0 & 0.0 & 0 & 0.0 & 0 & 0.0 \\
\hline \multicolumn{1}{|c|}{ Total } & 7 & 100.0 & 23 & 100.0 & 31 & 100.0 & 49 & 100.0 \\
\hline
\end{tabular}


Results presented in Table 1 showed that the total bacterial count could be detected in examined UHT milk and white soft cheese samples at varying percentages 40.0 and $72.0 \%$, with a mean counts/ $\mathrm{mL}$ or gm of $2.9 \times 10^{4}$ and $7.8 \times 10^{4}$, respectively. Lower prevalence in UHT milk was reported by Schaal and Noecker, 1977.

It is evident from the previously mentioned data that UHT milk samples yielded viable bacteria in 10 out of 25 samples and this normally unacceptable because sterilization or UHT treatment of milk are essential to ensure total microbial safety and enzymatic stability of milk (Korhonen et al., 1998) and allow prolonged self life of milk up to 6 months but the quality of packing especially its permeability proves to be very important (Reddy and Love, 1999). Also, mesophilic aerobic spore formers have ability to produce highly heat resistant spores that may survive sterilization or UHT treatment (Pettersson et al., 1996).

The higher total count was observed in examined white soft cheese samples due to several factors as the extent of handling in its production (Seligman, 1976), post pasteurization contamination, usually through contact with equipment surfaces or from the air and biofilms residing on surfaces which are one potential source of contamination (Austin and Bergeron, 1995).

Table 2 revealed that Staphylococci failed to be detected in UHT milk samples and could be isolated from 28.0, 40.0 and $64.0 \%$ from the examined plain yoghurt, fruit yoghurt and white soft cheese samples with a mean values/ gm of $1.2 \times 10^{3}, 1.3 \times 10^{3}$ and $3.4 \times 10^{3}$, respectively. The predominant isolated Staphylococci stains were Staphylococcus aureus and Staphylococcus epidermidis by frequency distribution of $(21.7,12.9$ and $20.4 \%) \&(26.2,29.0$ and $26.5 \%)$ of total isolates, respectively (Table, 6). Lower prevalence of Staphylococci in yoghurt was obtained by Arnott et al., 1974 while, in cheese lower incidences were recorded by Bastepe and Kösker, 1981; Papageorogiou et al., 1998 and Dipietro et al., 2004. Nearly similar count of Staphylococci in cheese was obtained by Ashenafi, 1990 while, higher counts were recorded by Mol and Vincentie, 1975 and Turantas et al., 1989 and a lower count was detected by Bastepe and Kösker, 1981.

The absence of Staphylococci in UHT milk samples due to the fact that they are heat labile microorganisms so destructed by heat but the biggest problem is the toxins which are heat stable so in UHT milk it is advisable to search about toxin of Staphylococci rather than the organism (Dunstall et al., 2005). The low prevalence of Staphylococci in yoghurt samples explained by the antagonistic effect of yoghurt against 
representative of conditionally pathogenic intestinal microorganisms as Proteus, Klebsiella, Para coli and Staph. aureus (Kockova et al., 1980).

Results summarized in Table 3 decleared that the Enterococci could be detected in 16.0, 20.0, 36.0 and $48.0 \%$ of examined UHT milk, plain yoghurt, fruit yoghurt and white soft cheese samples, respectively. The mean counts/mL or gm of Enterococci in examined samples were $1 \times 10^{3}, 1.4 \times 10^{3}, 1.98 \times 10^{3}$ and $1.95 \times 10^{3}$, respectively. The main isolated Enterococci stains were Enterococcus faecalis, Enterococcus faecium and Enterococcus durans by frequency distribution of (28.6, $21.7,19.4$ and $10.2 \%) \&(42.8,8.7,12.9$ and $14.3 \%)$ and $(0.0,0.0,3.2$ and $8.2 \%$ ) of total isolates, respectively (Table, 6). The results of UHT milk samples inagreement with that reported by Schaal and Noecker, 1977 who supposed that $10 \%$ of UHT milk packages proved to be faulty. Nearly similar percentage was detected in yoghurt samples by Arnott et al., 1974. While, in cheese samples Gelsomino et al., 2002 and Huys et al., 2003 could isolate the same Enterococci strains. Mikulec and Jovanovic, 2005 reported lower Enterococci counts and higher count obtained by Ashenafi, 1990.

Enterococci can be used as indicators of faecal contamination, they have been implicated in outbreaks of foodborne illness and they have been ascribed a beneficial or detrimental role in foods. Enterococci may survive heat processing and cause spoilage of the products as well as causing food infection (Franz et al., 1999).

Results tabulated in Table 4 revealed that E. coli failed to isolated from examined UHT milk samples. While, it could be isolated from 20.0, 28.0 and $28.0 \%$ of the examined plain yoghurt, fruit yoghurt and white soft cheese samples with a mean counts/ gm of $7.6 \times 10^{2}, 2.2$ $\times 10^{3}$ and $2.1 \times 10^{3}$, respectively. The E. coli isolated stains represented 21.7, 22.6 and $14.3 \%$ of total isolates, respectively (Table, 6). Arnott et al., 1974 reported lower percentage of $E$. coli in yoghurt samples. Meanwhile, Dipietro et al., 2004 and Brenda et al., 2005 obtained lower prevalences of $E$. coli in cheese and higher results were recorded by Ashenafi, 1990 and Papageoriou et al., 1998.

E. coli failed to be detected in UHT milk samples because the main source of this microorganism appear to be the intestinal tract of cattle (Bilici and Tayfur, 2002) and can't survive efficient sterilization or UHT treatment (Pettersson et al., 1996). The lower percentage of E. coli in yoghurt is due to acid adaptation ( $\mathrm{pH}$ 3.6-3.9) which reduce survival of E. coli (Yi and Chou, 2001). 
Table 5 showed that Clostridium perfringens failed to isolated from examined yoghurt samples. While, could be isolated from 8.0 and $12.0 \%$ of examined UHT milk and white soft cheese samples with a mean counts $/ \mathrm{ml}$ or $\mathrm{gm}$ of $0.9 \times 10^{3}$ and $3.3 \times 10^{3}$, respectively. Clostridium perfringens isolated stains represented 28.6 and $6.1 \%$ of total isolates, respectively (Table, 6). Turantas et al., 1989 could not isolate Clostridium perfringens from cheese while, Papageoriou et al., 1998 could isolate Clostridium perfringens with high percentages.

UHT milk samples contain Clostridium perfringens and this related to Clostridium is anaerobic spore formers so when spores present with faulty storage it will be grow and produce serious defects as putrefaction and acidification or other anomalies of taste (Schaal and Noecker, 1977). Clostridium perfringens could not detected in yoghurt and this may be due to increase lactic acid and titrimetric acidity as well as by a decrease in $\mathrm{pH}$ value (Pazakova et al., 1997).

Results mentioned in Table 6 reported that Campylobacter jejuni failed to be detected in the examined samples. The spreading of Campylobacter jejuni is mainly associated with food products of animal origin but products were always negative as a result of better controls in the processing of these products (Baffone et al., 1995).

Also, it is observed from this Table that Salmonellae failed to be detected in all examined samples. Nearly similar findings were obtained by Turantas et al., 1989 and Papageoriou et al., 1998 while, Grieger et al., 1976 found Salmonellae in milk products mainly cheese and explained this as a result of rennet produced by one enterprise. Also, Colak et al., 2007 could isolate Salmonellae from cheese.

Contamination of milk and dairy products by pathogenic microorganisms can be endogenous origin, following excretion from the udder of an infected animals or may be also of exogenous origin, through direct contact with infected herd or through environment (water $\&$ personnel). Heat treatment and processing of milk can inhibit or encourage the multiplication of microorganisms. Deficiencies in the hygienic measures of milk and dairy products storage, particularly refrigeration and in the HACCP plan that was not properly implemented should be corrected. It is important to inspect the manufacturing plant than to examine the single dairy product on the market.

\section{REFERENCES}


Adams, M.R. and Moss, M.O. (1995): Food Microbiology. Royal Society of Chemistry, Cambridge, U. K.

American Public Health Association (1992): Standard Methods for the examination of dairy products. $16^{\text {th }}$ Ed., American Public Health Association, New York.

Arnott, D.R.; Duitschaever, C.L. and Bullock, D.H. (1974): Microbiological evaluation of yoghurt produced commercially in Ontario. J. of Milk Food Technol., 37 (1): 11-13.

Ashenafi, M. (1990): Microbiological quality of ayib, a traditional Ethiopian cottage cheese. Int. J. of Food Microbiol., 10 (3-4): 263-8.

Austin, J.W. and Bergeron, C. (1995): Development of bacterial biofilms in dairy processing lines. J. of Dairy Res., 62: 509-519.

Bacteriological Laboratory of Hygiene and Environment Institute, Hohenheim University, 30 Garben St., 70599 Stuttgart, Germany.

Baffone, W.; Bruscolini, F.; Pianetti, A.; Biffi, M. R.; Brandi, G.; Selvaggio, L. and Albano, $V$. (1995): Diffusion of thermophilic Campylobacter in the Pesaro-urbino area (Italy) from 1985 to 1992. Eur. J. of Epidemiol., 11 (1): 83-6.

Bastepe, S. and Kösker, O. (1981): Coagulase positive Staphylococci from cheese and ice cream samples sold in Ankara and some biochemical properties of the isolates. Mikrobiyol. Bul., 15 (1): 55-63.

Bilici, S. and Tayfur, M. (2002): Escherichia coli and food infections. Sendrom, 14 (3): 60-70.

Bourlioux, P. and Pochart, P. (1988): Nutritional and health properties of yoghurt. World Rev Nutr Diet, 56: 217-58.

Brenda, P. M.; Mary, M.; James, F. B.; Deirdre, G.; Michael, T. R.; David, M. and Seamus, F. (2005): In-line milk filter analysis: Escherichia coli $\mathrm{O} 157$ surveillance of milk production holdings. Int. J. of Hygiene Environ. Health, 208: 407-413.

Buttriss, J. (1997): Nutritional properties of fermented milk products. Int. J. of Dairy Technol., 50: 21-7.

Chapman, G.H. (1945): The significance of sodium chloride in studies of staphylococci. J. of Bacteriol., 50: 201-203.

Codex Alimentarius Commission (2003): Report of the Thirty-Fifth Session of the Codex Committee on Food Hygiene, Alinorm 03/13A. 
Colak, H.; Hampikyan, H.; Bingol, E.B. and Ulusoy, B. (2007): Prevalence of Listeria monocytogenes and Salmonella spp. in Tulum cheese. Food Control, 18 (5): 576-579.

Condera, G.; Dalvit, P.; Martini, M.; Galero, G.; Gramaglia, M.; Goffredo, E.; Loffredo, G.; Morabito, S.; Ottavini, D.; Paterlini, F.; Pezzetti, G.; Pisanu, M.; Semproni, P. and Caprioli, A. (2004): Verocytotoxin-producing Escherichia coli O157 in minced beef and dairy products in Italy. Int. J. of Food Microbiol., 96: 67-73.

Dipietro, S.; Haritchabalet, K.; Cantoni, G.; Iglesias, L.; Manc, S.; Temperini, A.; Rosales, S.; Herrero, E.; Bigatti, R.; Orellana, $O$. and Larrieu, E. (2004): Surveillance of foodborne diseases in the Province of Rio Negro, Argentina, 1993-2001. Medicina, 64 (2): 120-4.

Dunstall, G.; Rowe, M. T.; Wisdom, G. B. and Kilpatrick, D. (2005): Effect of quorum sensing agents on the growth kinetics of Pseudomonas spp. of row milk origin. J. of Dairy Res., 72 (3): 276-80.

Fonberg-Broczek, M.; Arabas, J.; Kostrzewa, E.; Reps, A.; Szczawinski, J.; Szczepek, J.; Windyga, B. and Porowski, S. (1999): High pressure treatment of fruit, meat and cheese products: equipment, methods and results. In processing foods. Quality Optimization and Process Assessment Oliveira FAR, Oliveira JC, eds, pp 281-300.CRC press LIC.

Franz, C.M.; Holzafel, W.H. and Stiles, M.E. (1999): Enterococci at the crossroads of food safety. Int. J. of Food Microbiol., 1; 47 (12): $1-24$.

Gelsomino, R.; Vancanneyt, M.; Cogan, T: M.; Condon, S. and Swings, $J$. (2002): Source of Enterococci in farm house raw milk cheese. Appl. and Environ. Microbiol., 68 (7): 3560-3565.

Gelsomino, R.; Vancanneyt, M.; Timothy, M.C. and Jean, S. (2003): Effect of raw milk cheese consumption on the Enterococcal flora of human feces. Appl. and Environ. Microbiol., p.312319.

Grieger, C.; Havrila, J.; Hromada, H.; Lengyel, G.; Pakanova, M.; Perl, R. and Verdon, F. (1976): Rennet as a source of Salmonella occurrence in various dairy products. Vet. Med. (Praha), 21 (4): 221-7. 
Guarner, F. and Schaafsma, G.J. (1998): Probiotics. Int J. of Food Microbiol., 39: 237-8.

Hunt, J.M.; Abetya, C. and Tran, T. (2001): Campylobacter, INFDA Bacteriological analytical Manual on line. $8^{\text {th }}$ ed., rev. A. http: // www. Cfsan. fda. gov/ ebam-7. html. Accessed 5, 2005.

Huys, G.; D'Haene, K.; Collard, J.M. and Swings, J. (2003): Prevalence and molecular characterization of Tetracycline resistance in Enterococcs isolates from food. Appl. and Environ. Microbiol., 70 (3): $1555-1562$.

Jayarao, B.M. and Henning, D.R. (2001): Prevalence of foodborne pathogens in raw milk. J. of Dairy Sci., 84: 2157-2162.

Kockova, Z.; Stefanova, M.; Yankova, D. and Spassou, S. (1980): Clinical laboratory investigations in infants fed with adapted yogurt. Pediatriya, 19 (1): 68-74.

Korhonen, H.; Pihlanto-Leppälä, A.; Rantamäki, P. and Tupasella, T. (1998): Impact of processing on bioactive proteins and peptides. Trends Food Sci. Technol., 9: 307-319.

Longeveld, L.P.; Cuperus, F.; Van Breemen, P. and Dijkers, J. (1976): A rapid method for the detection of post-pasteurization contamination in HTST pasteurized milk. Neth. Milk Dairy j., 30: 157-173.

Maguire, H.C.; Bolye, M.; Lewis, J.; Pankhurst, A.A.; Wieneke, M.; Jacob, M.; Bruce,J. and O'Mahony, M. (1991): A large outbreak of food poisoning of unknown aetiology associated with stilton cheese. Epidemiol. Infect., 106: 497-505.

Mauriello, G.; Moio, L.; Genovese, A. and Ercolini, D. (2003): Relation ships between flavoring capabilities, bacterial composition and geographical origin of natural whey cultures (NWC) used for traditional water buffalo Mozzarella cheese manufacture. J. of Dairy Sci., 86: 486-497.

Mikulec, D.P. and Jovanovic, L: (2005): Microbiological study of fresh white cheese (Aserbian Craft Variety). Appl. Ecol. and Environ. Res., 4 (1): 129-134.

Mol, H. and Vincentie, H.M. (1975): Staphylococci in cheese made from raw milk (author's transl). Tijdschr Diergeneeskd, 15; 100 (18): 991-4.

Oliver, S.P.; Jayarao, B.M. and Almeida, R.A. (2005): Foodborne pathogens in milk and the dairy farm environment: Food safety and public health implications. Foodborne Pathogens and Disease, 2 (2): 115-129. 
Oxoid (1990): The Oxoid Manual. $6^{\text {th }}$ edition, Unipath. Ltd. U.K.

Özdemir, C.; Demirci, M.; Özdemir, S. and Sagdic, O. (2005): Production and some properties of yoghurt ice cream in Turkey. Milchwissenschaft, 60 (4): 419-422.

Papageorgiou, D.K.; Abrahim, A.; Bori, M. and Doundounakis, S. (1998): Chemical and bacteriological characteristics of Pichtogalo Chanion cheese and mesophilic starter cultures for its production. J. of Food Prot., 61 (6): 688-92.

Pazakova, J.; Turek, P. and Laciakova, A. (1997): The survival of Staphylococcus aureus during the fermentation and storage of yoghurt. J. of Appl. Microbiol., 82 (5): 659-662.

Pettersson, B.; Lembke, F.; Hammer, P.; Stackebrandt, E. and Priest, F. (1996): Bacillus sporothermodurans, a new species producing highly heat-resistant endospores. Int. J. of Syst. Bact., 46: 759764.

Reddy, M.B. and Love, M. (1999): The impact of food processing on the nutritional quality of vitamins and minerals. Pages 99-106 in Impact of processing on food safety. Jackson, L. S.; Knize, M. G. and Morgan, J. N., ed. Kluwer Academic/Plenum Publishers, New York.

Schaal, E. and Noecker, F. (1977): Investigation on the microbial quality of commercial UHT milk products. Archiv Für Lebensmittel Hygiene, 28 (2): 56-61.

Seligman, R. (1976): Staphylococci in foods: recent achievements of food industries and public health authorities (Hebrew). Harefuah, 91 (10): 348-352+375.

Turantas, F.; Unlütürk, A. and Göktan, D. (1989): Microbiological and compositional status of Turkis white cheese. Int. J. of Food Microbiol., 8 (1): 19-24.

Yi, C.H. and Chou, C.C. (2001): Acid adaptation and temperature effect on the survival of E. coli O157: $\mathrm{H} 7$ in acidic fruit juice and lactic fermented milk product. Int. J. of Food Microbiol., 70: 189-195. 